\title{
Photoaffinity Labelling of the Insulin Receptor in Intact Rat Hepatocytes, Mouse Soleus Muscle, and Cultured Human Lymphocytes
}

\author{
M.Fehlmann ${ }^{1}$, Y.Le Marchand-Brustel ${ }^{1}$, E. Van Obberghen ${ }^{1}$, D. Brandenburg² and P.Freychet ${ }^{1}$ \\ ${ }^{1}$ Unité de Recherches sur les Hormones Polypeptidiques et la Physiopathologie Endocrinienne (INSERM U 145) \\ and Laboratoire de Médecine Expérimentale, Faculté de Médecine, Nice, France and ${ }^{2}$ Deutsches Wollforschungs-Institut, Aachen, FRG
}

\begin{abstract}
Summary. Using the photoreactive, biologically active insulin analogue, B2-(2 nitro, 4-azidophenylacetyl) des- $\mathrm{Phe}^{\mathrm{B} 1}$ insulin, which can be covalently bound to receptor molecules upon photolysis, the insulin receptor has been studied in three different types of cells or tissues: isolated rat hepatocytes, intact murine soleus muscle and cultured human lymphocytes. When compared with native insulin, this analogue displayed a slightly reduced binding affinity. Accordingly, the biological potency of the photoreactive analogue was decreased by approximately $30 \%$ compared with native insulin when tested for its ability to stimulate amino acid transport in hepatocytes, and deoxyglucose uptake in soleus muscles. It was as effective as insulin, however, at maximally stimulating concentrations
\end{abstract}

and therefore is a full insulin agonist. This photoprobe was used to specifically label the insulin receptor in the three tissues: after ultra-violet irradiation, sodium dodecyl sulphatepolyacrylamide gel analysis of extracts under reducing conditions revealed that most of the radioactivity was associated with a 130,000 dalton band. In isolated hepatocytes, two bands at 125,000 and 23,000 daltons were also specifically labelled. In three different cell types from three different animal species, the 130,000 dalton band appeared to be the major subunit of the insulin receptor.

Key words: Insulin, insulin receptors, mouse skeletal muscle, rat hepatocytes, human lymphocytes, photoaffinity labelling.
Binding of insulin to specific receptors located on the surface of target cells is the first step in the hormone's action. Recently, two methods have been developed which result in a non-reversible, covalent binding of insulin to its receptors. These methods involve either a chemical cross-linking of the hormone to its receptor [1, 2], or the use of photoreactive insulin analogues which upon photolysis can be covalently bound to receptor molecules [3-6]. Covalent binding of radiolabelled insulin to membrane components has allowed considerable progress in the knowledge of the subunit structure of the insulin receptor. Most studies, however, involving either the chemical cross-linking of insulin to its receptor $[1,2]$ or the use of photoreactive insulin [3-6] have been performed on membrane preparations, which precludes an exploration of the dynamics of the receptor in the living cell. The present study was thus designed not only to study the binding properties and biological activity of the photoreactive analogue B2-(2 nitro, 4-azidophenylacetyl)des-Phe ${ }^{\mathrm{B} 1}$ insulin, but more importantly to investigate the possibility of labelling the insulin receptor in situ in intact isolated rat hepatocytes, murine soleus muscle and cultured human lymphocytes.

\section{Materials and Methods}

\section{Chemicals}

The photoreactive insulin analogue, B2(2 nitro, 4-azidophenylacetyl)des-Phe ${ }^{\mathrm{B} 1}$ insulin, was prepared as previously described [6-8] and iodinated in the dark to a specific activity of $200-250 \mu \mathrm{Ci} / \mu \mathrm{g}$ using a modification of the chloramine T method [referred to as the second modification in reference 9]. Porcine monocomponent insulin was generously supplied by the Novo Research Institute, Copenhagen, Denmark. $\mathrm{Na}^{125} \mathrm{I}$ was purchased from the Commissariat à l'Energie Atomique, Saclay, France; $\alpha$-amino- $1\left({ }^{14} \mathrm{C}\right)$ isobutyric acid and 2-deoxy-D-1 $\left({ }^{14} \mathrm{C}\right)$ glucose were from the Radiochemical Centre, Amersham, UK. Bovine serum albumin, $\alpha$-aminoisobutyric acid, gentamycin, bacitracin, phenylmethylsulphonyl fluoride (PMSF) and N2-hydroxyethylpiperazine- $\mathrm{N}^{\prime}$-2-ethanesulphonic acid (Hepes) were from Sigma, St. Louis, USA. RPMI 1640 medium (Roswall Park Memorial Institute Medium) was from Gibco Bio-Cult Ltd (Paisley, UK). All other reagents were of the best grade commercially available.

\section{Isolated Hepatocytes, Liver Plasma Membranes, and Soleus Muscles}

Hepatocytes were isolated from male Wistar rats (120-150 g) by collagenase digestion of the liver [10] and incubated in Krebs-Ringer bicarbonate buffer ( $\mathrm{pH} 7.4$ ), containing $10 \mathrm{mg} / \mathrm{ml}$ dialysed bovine se- 
rum albumin (Fraction V), gentamycin $(50 \mu \mathrm{g} / \mathrm{ml})$, bacitracin $(0.8 \mathrm{mg}$ / $\mathrm{ml})$ and PMSF $(2 \mathrm{mmol} / \mathrm{l})$ and gassed with $\mathrm{O}_{2}: \mathrm{CO}_{2}(95: 5, \mathrm{v}: \mathrm{v})$. The effect of the photoreactive insulin and native insulin on $\alpha$-aminoisobutyric acid influx was investigated in isolated hepatocytes exposed to varying concentrations of peptides for $2 \mathrm{~h}$ (this time was required for the full expression of the hormonal effect [10]). Soleus muscles were isolated from 8-week-old male Swiss albino mice and incubated in Krebs Ringer bicarbonate buffer ( $\mathrm{pH} 7.4$ ), containing defatted bovine serum albumin $(20 \mathrm{mg} / \mathrm{ml})$ and pyruvate $(2 \mathrm{mmol} / 1)$, and gassed. The uptake of 2-deoxyglucose in muscles was measured at $37^{\circ} \mathrm{C}$ as previously described [11] in the absence or presence of varying concentrations of native or photoreactive insulin. All biological assays were conducted in the dark. Partially purified liver plasma membranes (step 11 in reference 12) were used.

\section{Cultured IM-9 Lymphocytes}

Human cultured lymphocytes of the IM-9 line were grown at $37^{\circ} \mathrm{C}$ in RPMI 1640 medium containing 10\% fetal calf serum. Glutamine $(0.3 \mathrm{mg} / \mathrm{ml})$ was added just before feeding. Cells were fed three times a week by dividing the culture $1: 3$ and adding fresh medium. Cells in late log phase or early stationary phase of growth were split $1: 2$ in fresh medium $24 \mathrm{~h}$ before use. The cells were removed from the growth medium by centrifugation at $600 \mathrm{~g}$ for $5 \mathrm{~min}$ at $24^{\circ} \mathrm{C}$ and washed once by resuspension in the assay buffer. The washed cell pellet was then equilibrated in assay buffer at $15^{\circ} \mathrm{C}$. Approximately $2 \times$ $10^{6}$ cells $/ \mathrm{ml}$ were incubated in assay buffer $(50 \mathrm{mmol} / 1$ sodium Hepes; $120 \mathrm{mmol} / 1 \mathrm{NaCl} ; 1.2 \mathrm{mmol} / 1$ magnesium sulphate; $1 \mathrm{mmol} / 1$ EDTA; $10 \mathrm{mmol} / 1$ glucose; $15 \mathrm{mmol} / 1$ sodium acetate; $10 \mathrm{mg} / \mathrm{ml}$ bovine serum albumin, and $2 \mathrm{mmol} / 1 \mathrm{PMSF}$; $\mathrm{pH} 7.6$ ).

\section{Binding Studies}

The binding of ${ }^{125} \mathrm{I}$-insulin and ${ }^{125} \mathrm{I}$-photoreactive insulin was measured in the dark, under steady state conditions, as previously described for isolated hepatocytes [13], isolated soleus muscles [11], cultured human lymphocytes [14], and liver plasma membranes [9] using $0.3 \mathrm{ng} / \mathrm{ml}(0.05 \mathrm{nmol} / \mathrm{l})$ of native or photoreactive ${ }^{125} \mathrm{I}$-insulin and varying concentrations of corresponding unlabelled insulin. For gel analysis, labelled insulin concentration was increased to $10 \mathrm{nmol} / 1$.

\section{Irradiation Procedure}

All irradiations were conducted using a water-cooled high pressure mercury lamp (Philips HPK $125 \mathrm{~W} / \mathrm{L}$ ). The light was filtered through a black glass filter and the biological materials were irradiated for $3 \mathrm{~min}$ at a distance of $9 \mathrm{~cm}$ from the lamp, as described by Fehlmann et al. [8]. This procedure has been shown not to modify the morphology of the cells or their ability to transport actively aminoisobutyric acid [8]. The efficacity of the crosslinking procedure was $12-15 \%$ [8].

\section{Polyacrylamide Gel Electrophoresis (PAGE)}

At the end of irradiation, hepatocytes, soleus muscles, IM-9 lymphocytes and liver membranes were directly solubilized in $3 \%(\mathrm{w} / \mathrm{V})$ boiling sodium dodecylsulphate (SDS) solution containing $10 \%$ glycerol $(\mathrm{v} / \mathrm{v}), 2 \% \beta$-mercaptoethanol (v/v) and $0.01 \%$ bromophenol blue (w/ v). Lysates were further boiled for $4 \mathrm{~min}$. Analysis of the samples by one-dimensional slab-gel, using a 5-15\% linear gradient of acrylamide as a resolving gel and a 3\% stacking gel, was performed according to Laemmli [15]. The gels were stained with Coomassie blue, fluorographed and vacuum dried; autoradiography was carried out by exposing the gels to Kodak X-OMAT-R film. The proteins used as molecular weight markers were: myosin heavy chain $(200 \mathrm{~K}), \beta$-galactosidase $(116 \mathrm{~K})$, phosphorylase $\mathrm{b}(94 \mathrm{~K})$, bovine serum albumin $(67 \mathrm{~K})$, ovalbumin $(43 \mathrm{~K})$, carbonic anhydrase $(30 \mathrm{~K})$, soybean trypsin inhibitor $(20 \mathrm{~K})$, and lysozyme $(14.4 \mathrm{~K})$.

\section{Results}

\section{Receptor-Binding Properties of Photoreactive Insulin}

In the three biological systems tested (isolated rat hepatocytes, isolated mouse soleus muscles and human IM-9 lymphocytes), photoreactive insulin binding was $30-35 \%$ lower than native insulin binding at low peptide concentrations (Fig. 1). Scatchard analysis of the data (not shown) revealed that the photoreactive insulin analogue had a moderately reduced affinity $(30-35 \%$ lower than that of native insulin) for the receptor, while it was capable of binding to the same number of total insulin receptors.

\section{Biological Activity of Photoreactive Insulin}

Insulin has previously been shown to stimulate amino acid transport in isolated rat hepatocytes $[10,16]$. As shown in Figure 2 a, maximal responses of $\alpha$-aminoisobutyric acid transport were identical for the two insulins (approximately a twofold increase above basal). The concentration producing a half-maximal response was slightly higher for the photoreactive insulin $\left(\mathrm{EC}_{50}\right.$ approximately $1.7 \mathrm{nmol} / 1)$ than for native insulin $\left(\mathrm{EC}_{50}\right.$ approximately $1.1 \mathrm{nmol} / \mathrm{l}$ ). In isolated soleus muscles, photoreactive insulin also maximally stimulated 2-deoxyglucose uptake (an index of the rate of glucose transport and phosphorylation) to the same extent as native insulin (Fig. 2b). As seen in hepatocytes, the $\mathrm{EC}_{50}$ was higher with photoreactive insulin (approximately $0.5 \mathrm{nmol} / 1$ ) than with native insulin (approximately $0.4 \mathrm{nmol} / 1)$.

\section{Photoaffinity Labelling of Insulin Receptors}

After the ${ }^{125}$ I-labelled photoreactive insulin analogue had been allowed to bind in the dark, cells or muscles were irradiated, solubilized and extracts were analysed by SDS-PAGE under reducing conditions. As shown in Figure 3 , the radioactivity was specifically located in a few bands: in hepatocytes (lane A), three bands were visible with molecular weights of $130,000,125,000$ and 23,000 daltons; in muscles (lane D) the radioactivity was associated predominantly with a 130,000 -dalton band; in IM-9 lymphocytes (lane G), a 130,000 and a 98,000 -dalton component were labelled. All those bands were attenuated or suppressed when unlabelled insulin at $10 \mathrm{nmol} / 1$ (lanes $\mathrm{B}$ and $\mathrm{E}$ ) or $1 \mu \mathrm{mol} / \mathrm{l}$ (lanes $\mathrm{C}, \mathrm{F}$ and $\mathrm{H}$ ) was present during the association period. In order to elucidate whether the 123,000 -dalton component, which was observed only with hepatocytes, was a characteristic of the liver insulin receptor or alternatively a degradation product generated during the isolation of the cells, liver plasma membranes were incubated with the photoreactive analogue (Fig. 4). When the binding was performed in the presence of the inhibitor of proteolysis PMSF, only one labelled band with a 

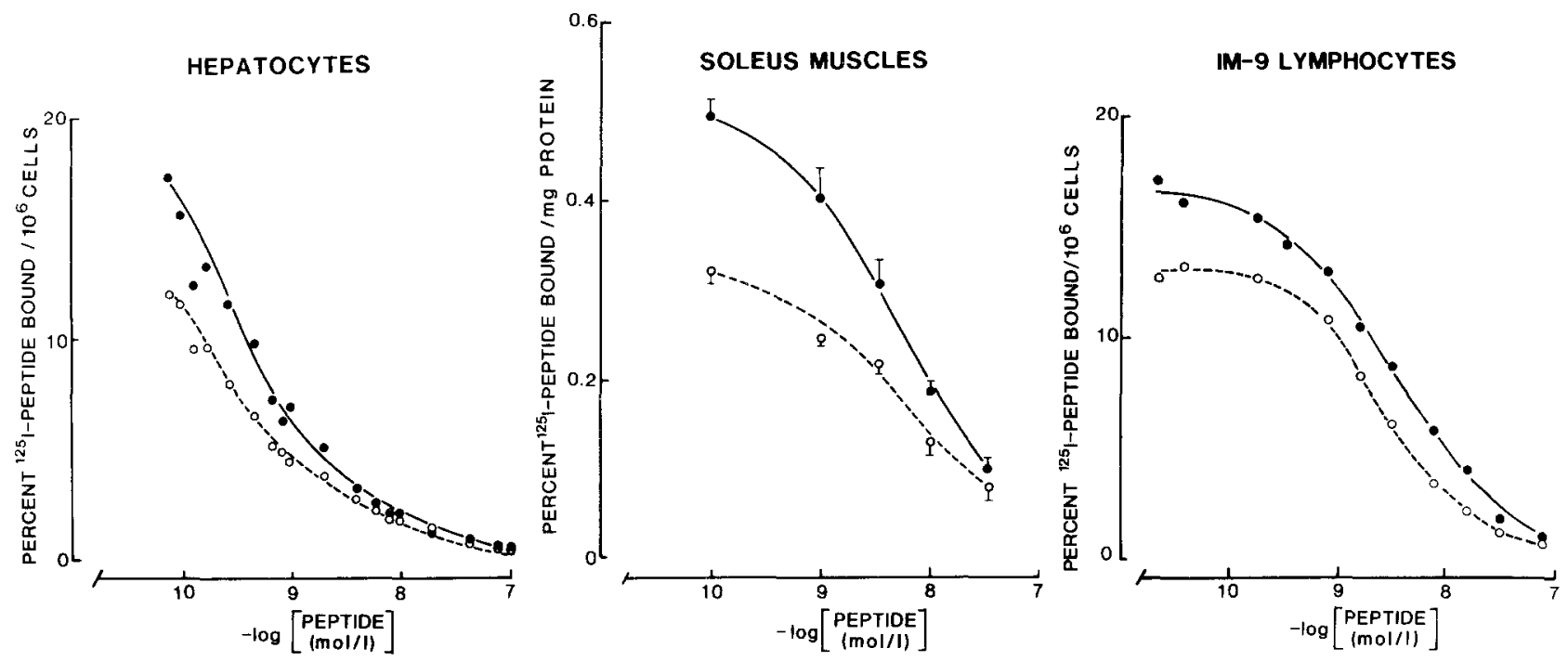

Fig. 1. Binding of ${ }^{125} \mathrm{I}$-photoreactive insulin $(\mathrm{O}-\ldots \mathrm{O})$ and ${ }^{125} \mathrm{I}$-insulin $(-1)$ to rat hepatocytes, mouse soleus muscles, and cultured human lymphocytes. The ${ }^{125}$ I-labelled peptide $(0.05 \mathrm{nmol} / \mathrm{l})$ was incubated with hepatocytes $\left(10^{6} \mathrm{ml}\right)$ for $1 \mathrm{~h}$ at $20^{\circ} \mathrm{C}$, with individual soleus muscles for $4 \mathrm{~h}$ at $20^{\circ} \mathrm{C}$, and with IM-9 lymphocytes for $90 \mathrm{~min}$ at $15^{\circ} \mathrm{C}$, in the absence or presence of varying concentrations of the corresponding unlabelled peptide. All experiments were carried out in the dark. Data are expressed as percentage of ${ }^{125}$ I-peptide specifically bound. Results correspond to one representative experiment for hepatocytes and IM-9 lymphocytes. For soleus muscles, each point represent the mean \pm SEM of six to eight individual muscles

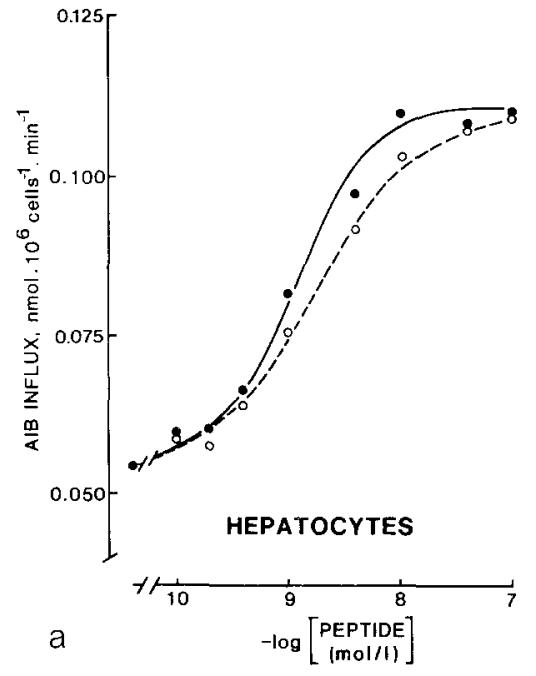

molecular weight of 130,000 was observed (lane A). However, when PMSF was omitted from the incubation mixture, a 125,000-dalton and a 23,000-dalton band were also present (lane C), which is similar to the situation found with isolated hepatocytes. All of those bands (i.e. 130,$000 ; 125,000$ and 23,000-dalton bands) were absent when membranes were incubated with an excess of unlabelled insulin (lanes B and D).

\section{Discussion}

A major breakthrough in the elucidation of the insulin receptor structure recently occurred with the development of photoaffinity probes and the use of bifunction- al chemical agents to covalently crosslink radiolabelled insulin and receptor proteins $[1-8,17,18]$. In the present study, we have used a photoreactive analogue which is a full insulin agonist; this analogue displayed no decrease in maximal activity in the different systems tested (isolated hepatocytes and soleus muscle), while its binding affinity and its biological potency were slightly decreased when compared with native insulin. This analogue is thus a valid tool to investigate the structure and function of the insulin receptor.

The data reported in the present study show that the major insulin binding subunit labelled in situ in two intact cell types (isolated rat hepatocytes and cultured human lymphocytes) and in an intact isolated organ (the mouse soleus muscle) is a 130,000 -dalton component. 


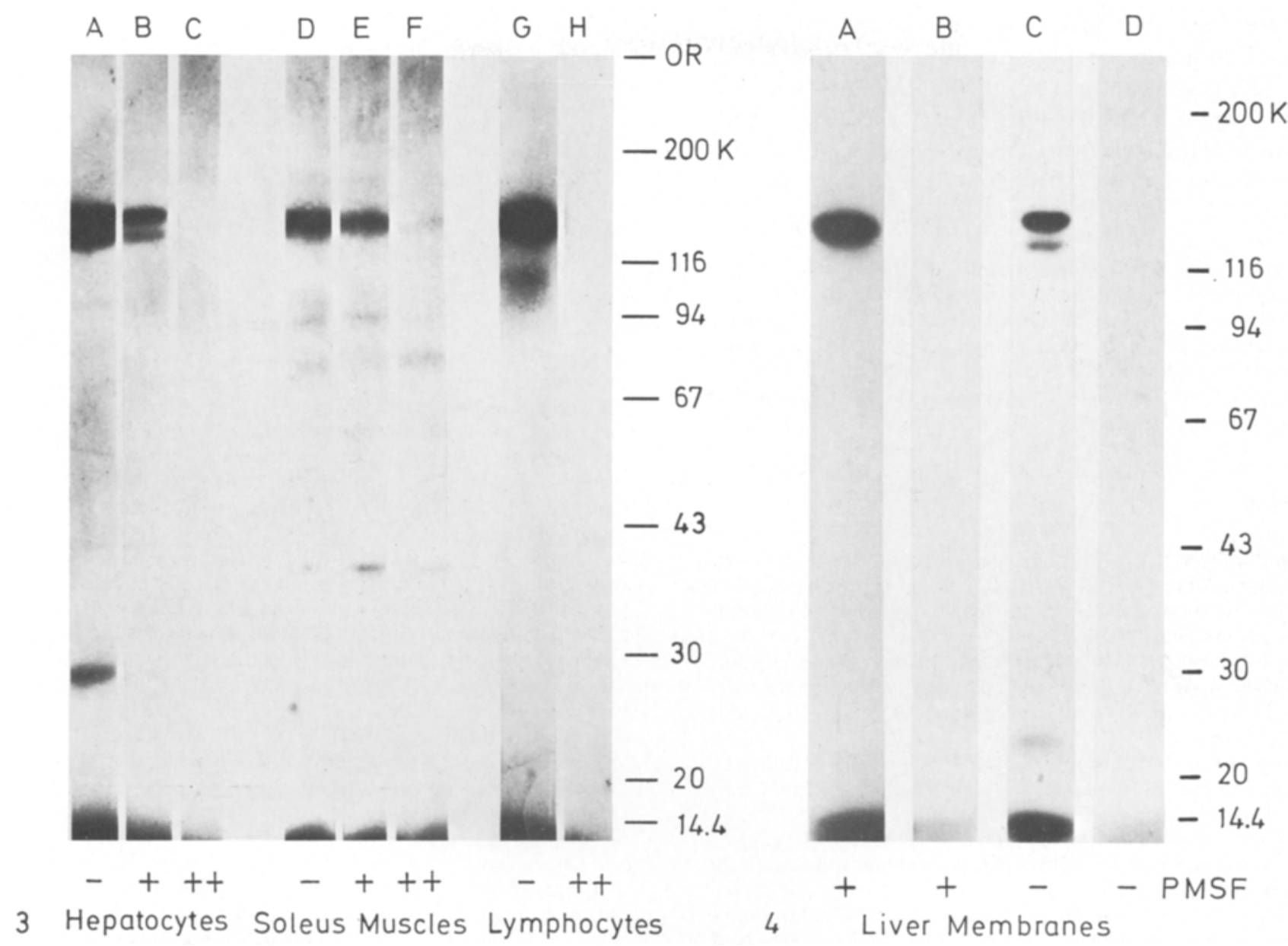

Fig. 3. Photoaffinity labelling of insulin receptors in isolated hepatocytes, soleus muscles, and IM-9 lymphocytes. Samples were incubated in the dark with $10 \mathrm{nmol} / 1$ of ${ }^{125} \mathrm{I}$-photoreactive insulin for $2 \mathrm{~h}$ at $15^{\circ} \mathrm{C}$ (hepatocytes and lymphocytes) or $4 \mathrm{~h}$ at $20^{\circ} \mathrm{C}$ (muscles) in the absence $(-)$ or presence of $10 \mathrm{nmol} / \mathrm{l}(+)$ or $1 \mu \mathrm{mol} / \mathrm{l}(++)$ of unlabelled insulin. The samples were then ultra-violet-irradiated and processed for SDS-PAGE as described in Materials and Methods. $\mathrm{OR}=$ origin

Fig.4. Photoaffinity labelling of insulin receptor in liver plasma membranes. Puriffed liver plasma membranes $(0.25 \mathrm{mg}$ protein $/ \mathrm{ml})$ were incubated in the dark for $2 \mathrm{~h}$ at $15^{\circ} \mathrm{C}$ with $7.5 \mathrm{nmol} / 1$ of ${ }^{125} \mathrm{I}$-photoreactive insulin in the presence or absence of PMSF, and without (lanes A and C) or with (lanes B and D) $5 \mu \mathrm{mol} / 1$ unlabelled insulin. The samples were then ultra-violet-irradiated, and processed for SDS-PAGE as described in Materials and Methods. OR = origin

This result agrees with that obtained after crosslinking of insulin and its receptor using a bifunctional reagent, and analysis of solubilized proteins by gel electrophoresis under reducing conditions $[17,18]$. A minor 98,000 dalton band could also be detected in IM-9 lymphocytes. The existence of such a smaller subunit of the insulin receptor has been the subject of controversy in the past. This band was heavily labelled when biosynthetic labelling of the receptor was performed using ${ }^{35} \mathrm{~S}$-methionine $[19,20]$ or ${ }^{3} \mathrm{H}$-monosaccharides [20, 21], followed by immunoprecipitation of the receptor with a specific anti-receptor antibody. Such a band was observed also in liver membranes after photoaffinity labelling [4], but not in the present study. The fact that this 98,000 band was labelled in studies using affinity labelling and thus involving the binding site of the receptor, suggests that this 98,000 subunit is one (or part) of the binding site(s) for insulin. It is presently unclear why this band was de- tected only in IM-9 lymphocytes in our study. The present data do not exclude the possibility that the 98,000 dalton component represents a proteolytic fragment of the 130,000-dalton subunit. In isolated hepatocytes, in addition to the 130,000-dalton subunit, two bands $(125,000$ and 23,000 daltons respectively) were also specifically labelled. The fact that those bands were also present in liver membranes, but only when membranes were incubated in the absence of a protease inhibitor, suggests that these two bands in hepatocytes represent proteolytic fragments of the 130,000 -dalton receptor subunit.

In conclusion, we have shown that: (1) the B2-photoreactive insulin derivative is a full insulin agonist with a slightly reduced affinity and biological potency; (2) this photoprobe can be used to specifically label the insulin receptor in intact cells in situ and even in an isolated organ; (3) in three different cell types from three dif- 
ferent species (rat, mouse, and man) the specific labelling predominantly involves a 130,000-dalton band, which appears to be the major recognition moiety of the insulin receptor. Photoaffinity labelling of the insulin receptor in intact cells provides us with a powerful tool to investigate the fate of the insulin-receptor complex in intact cells.

Acknowledgements. We thank Ms A.Kowalski and Mrs. N.GrenierBrossette for their excellent technical assistance. We are grateful to Mr. G. Visciano for the illustration work and to Ms. J. Duch for secretarial assistance. This study was supported by grant 80.7 .0187 from the Délégation Générale à la Recherche Scientifique et Technique, Paris, France and by Sonderforschungsbereich 113 (Diabetesforschung), Düsseldorf, FRG

\section{References}

1. Pilch PF, Czech MP (1979) Interaction of cross-linking agents with the insulin effector system of isolated fat cells. Covalent linkage of ${ }^{125} \mathrm{I}$-insulin to a plasma membrane receptor protein of $140,000 \mathrm{dal}-$ tons. J Biol Chem 254: 3375-3381

2. Pilch PF, Czech MP (1980) The subunit structure of the high affinity insulin receptor. Evidence for a disulfide-linked receptor complex in fat cell and liver plasma membranes. J Biol Chem 255: $1722-1731$

3. Yip CC, Yeung CWT, Moule ML (1978) Photoaffinity labeling of insulin receptor of rat adipocyte plasma membrane. J Biol Chem 253: 1743-1745

4. Yip CC, Yeung CWT, Moule ML (1980) Photoaffinity labeling of insulin receptor proteins of liver plasma membrane preparations. Biochemistry 19: 70-76

5. Jacobs S, Hazum E, Shechter Y, Cuatrecasas P (1979) Insulin receptor: covalent labeling and identification of subunits. Proc Natl Acad Sci USA 76: 4918-4921

6. Wisher MH, Baron MD, Jones RH, Sönksen PH, Saunders DJ, Thamm P, Brandenburg D (1980) Photoreactive insulin analogues used to characterise the insulin receptor. Biochem Biophys Res Commun 92: 492-498

7. Thamm P, Saunders D, Brandenburg D (1980) Photoreactive insulin derivatives: preparation and characterization. In: Brandenburg D, Wollmer A (eds) Insulin chemistry, structure and function of insulin and related hormones. de Gruyter, New York, pp 309-316

8. Fehlmann M, Carpentier JL, Le Cam A, Thamm P, Saunders D, Brandenburg D, Orci L, Freychet P (1982) Biochemical and morphological evidence that the insulin receptor is internalized with insulin in hepatocytes. J Cell Biol 93: 82-87
9. Freychet $\mathbf{P}$ (1976) Insulin receptors. In: Blecher $M$ (ed) Methods in receptor research. Dekker, New York, pp 385-428

10. Fehlmann M, Le Cam A, Freychet P (1979) Insulin and glucagon stimulation of amino acid transport in isolated rat hepatocytes. Synthesis of a high affinity component of transport. J Biol Chem 254: 10431-10437

11. Le Marchand-Brustel Y, Freychet P (1979) Effect of fasting and streptozotocin diabetes on insulin binding and action in the isolated mouse soleus muscle. J Clin Invest 64: 1505-1515

12. Neville DM (1968) Isolation of an organ specific protein antigen from cell surface membrane of rat liver. Biochim Biophys Acta 154: $540-552$

13. Fehlmann M, Morin O, Kitabgi P, Freychet P (1981) Insulin and glucagon receptors of isolated rat hepatocytes: comparison between hormone binding and amino acid transport stimulation. Endocrinology 109: 253-261

14. Van Obberghen E, De Meyts P, Roth J (1976) Cell surface receptors for insulin and human growth hormone. Effect of microtubule and microfilament modifiers. J Biol Chem 251:6844-6851

15. Laemmli UK (1970) Cleavage of structural proteins during the assembly of the head of bacteriophage $\mathrm{T}_{4}$. Nature 227:680-685

16. Le Cam A, Freychet $\mathbf{P}$ (1978) Effect of insulin on amino acid transport in isolated rat hepatocytes. Diabetologia 15: 117-123

17. Kasuga M, Van Obberghen E, Yamada KM, Harrison LC (1981) Autoantibodies against the insulin receptor recognize the insulin binding subunits of an oligomeric receptor. Diabetes 30:354-357

18. Massague J, Pilch PF, Czech MP (1980) Electrophoretic resolution of three major insulin receptor structures with unique subunit stoichiometries. Proc Natl Acad Sci USA 77: 7137-7141

19. Van Obberghen E, Kasuga M, Le Cam A, Hedo JA, Itin A, Harrison LC (1981) Biosynthetic labeling of insulin receptor: studies of subunits in cultured human IM-9 lymphocytes. Proc Natl Acad Sci USA 78: 1052-1056

20. Van Obberghen E, Le Cam A (1981) Identification and turnover of the insulin receptor in primary cultures of adult rat hepatocytes. Diabetologia 21: 339 (Abstract)

21. Hedo JA, Kasuga M, Van Obberghen E, Roth J, Kahn CR (1981) Direct demonstration of glycosylation of insulin receptor subunits by biosynthetic and external labeling: evidence for heterogeneity. Proc Natl Acad Sci USA 78: 4791-4795

Received: 24 November 1981

and in revised form: 24 June 1982

Y.Le Marchand-Brustel

INSERM U 145

Faculté de Médecine (Pasteur)

Chemin de Vallombrose

F-06034 Nice Cedex

France 